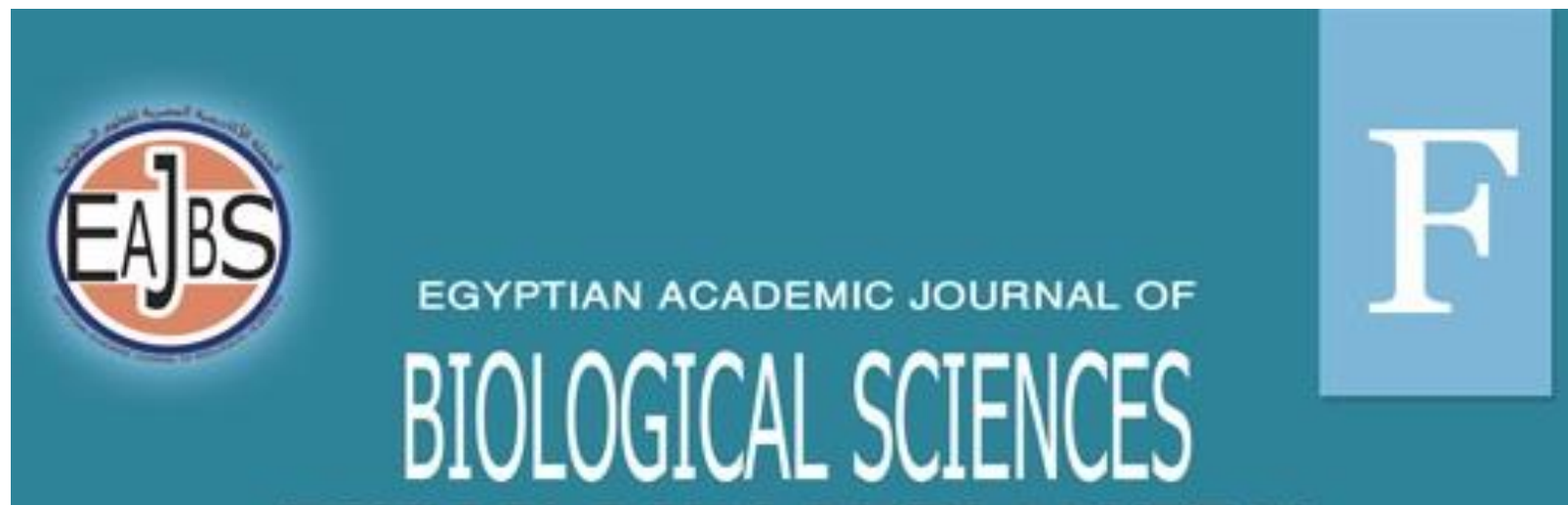

TOXICOLOGY \& PEST CONTROL

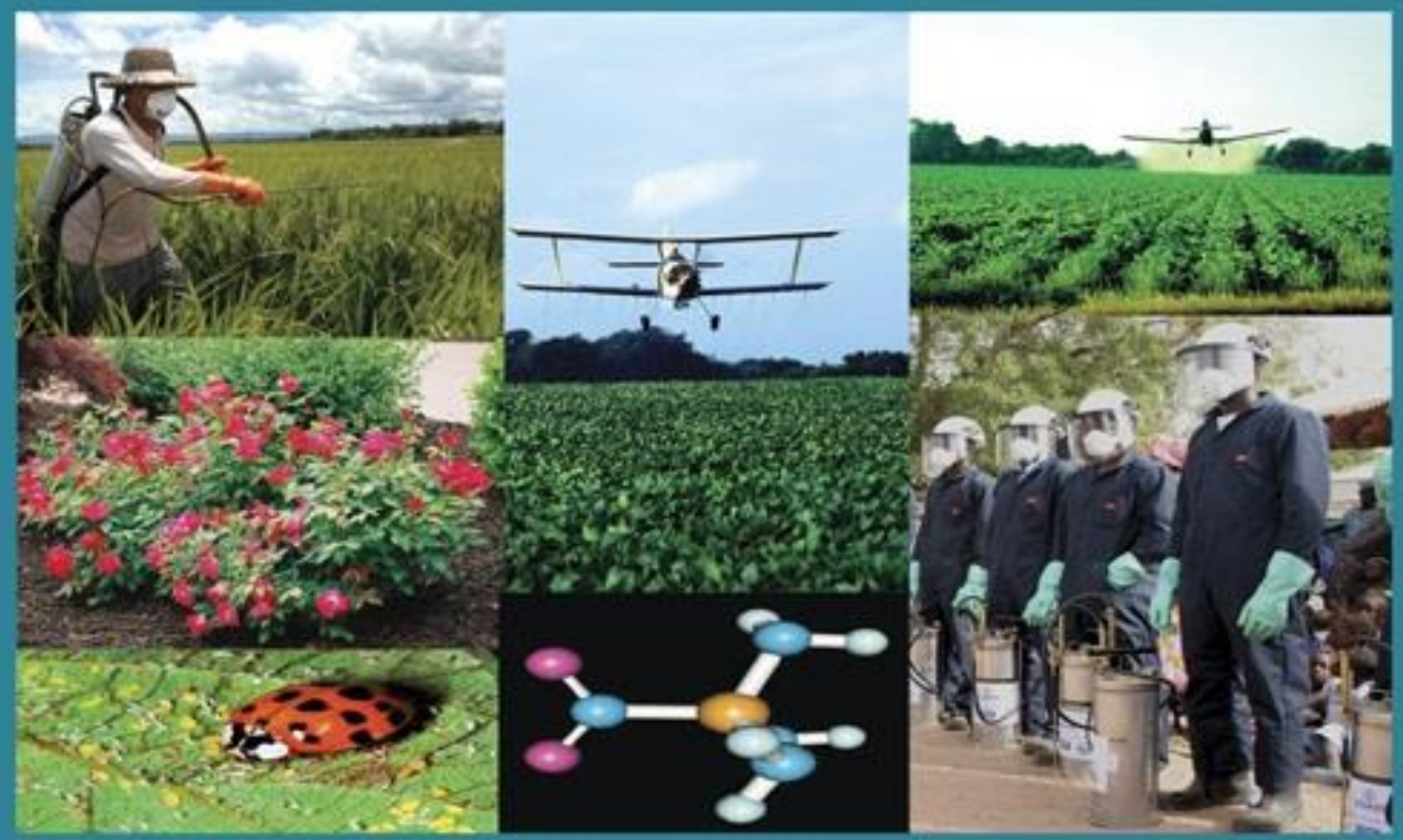

ISSN

2090-0791

WWW.EAJBS.EG.NET

Vol. 13 No. 1 (2021)

$\underline{\text { www.eajbs.eg.net }}$

Citation: Egypt. Acad. J. Biolog. Sci. (F.Toxicology \& Pest control) Vol.13(1)pp255-260(2021)

DOI: 10.21608/EAJBSF.2021.166017 
Egypt. Acad. J. Biolog. Sci., 13(1):255- 260 (2021)

Egyptian Academic Journal of Biological Sciences

F. Toxicology \& Pest Control

ISSN: 2090 - 0791

http://eajbsf.journals.ekb.eg/

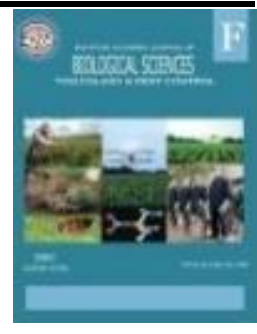

\section{Joint Action of Neem and Metarhizium acridum on Immature Adults of Desert Locust, Schistocerca gregaria (Forskal)}

Abdelatef G. M. M. and El-Dydamony M. Kh.

Locust and Grasshoppers Research Dept., Plant Protection Research Institute, Agricultural Research Centre, Egypt

E-Mail: mohamedkhyri@gmail.com

\section{ARTICLE INFO}

Article History

Received: 24/1/2021

Accepted: 3/4/2021

\section{Keywords:}

Energy

metabolism, lactate

dehydrogenase,

immature adults,

Schistocerca

gregaria, Neem,

Metarhizium

acridum.

\section{INTRODUCTION}

Locusts and grasshoppers are considered as the most destroying and a threat to pests agriculture worldwide and responsible for significant loss to the agricultural industry in grassland biomes of the world (Sumit et al., 2020 and wanxi et al., 2020). Threats of locusts and grasshoppers required the application of a huge number of chemical pesticides which rise the risk of environmental pollution, therefore entomopathogenic fungi may be suitable microbial control agents that infect their host through the cuticle with a possibility to mass-produce cheaply and are target specific (Lomer et al., 2000). M. acridum proved to be a good solution as an alternative agent for locust and grasshoppers' control in Egypt, (Elmaghraby et al., 2009). Plant phytochemicals may also play important role in reducing pesticides programs, Neem tree one of the richest plants with toxic phytochemicals (Jacobson, 1989 and Abdulhadi and Kashere 2020).Azadirachtin (the most active compound of Neem tree) directly interferes with the endocrine system of insects and causes ecdysteroid and juvenile hormone titers imbalance (Subrahmanyam and Rembold., 1989). Trehalase and lactate dehydrogenase are very important enzymes for energy in haemolymph of locust and grasshoppers. Trihalase hydrolyse the trehalose sugar in irreversible action to produce 2 glucose units and energy, (Becker et al., 1996 and Wegener, 1996). While lactate dehydrogenase plays important role in carbohydrate metabolism it is activity indicates active energy metabolism (Diamantino et al., 2001 and Hamadah et al, 2010). The present study aims to investigate the joint action of Neem and fungi Metarhizium acridum on mortality 
and their effect on two important energy enzymes of the haemolymph of immature adults of desert locust $S$. gregaria.

\section{MATERIALS AND METHODS}

\section{Insect Tested:}

Immature adults of the desert locust $S$. gregaria two days after final molting were used in the present experiments and taken from maintained culture for several generations at the Locust and Grasshoppers Research Department, Plant Protection Research Institute (PPRI), Agriculture Research Center (ARC), Dokki, Giza. Desert locust was reared in the laboratory according to Hunter-Jones (1961) and fortified with insects collected from the field whenever possible.

\section{Metarhizium acridum:}

The entomopathogenic fungus used during the present study was M. acridum isolate (IMI330189) from BASF Company, South Africa, under the commercial name Green Muscle ${ }^{\circledR}$. The conidia of the fungus were suspended in sterilized water, then a trace of Tween (80) was added to be emulsified. The concentration was adjusted to $5 \times 10^{8}$ spores $/ \mathrm{ml}$., each nymph received $5 \mu l$, while the control nymphs were treated with $5 \mu 1$ of sterilized water and traces of Tween (80) (El-Dydamony, 2011).

Neem (Azaderachtin):

Tenth of the recommended dose from commercial product Safe oil was used $(1 \mathrm{ml}$ $\backslash 1$ litter). Each treated nymph received $5 \mu$ l.

Neem, and Metarhizium acridum Mixture:

Neem Solution was prepared as previously then $M$. acridum spores were suspended in that solution with a trace of Tween 80 and the concentration was adjusted to $5 \times 10^{8}$ spores/ml., each nymph received $5 \mu 1$.

Statistical Analyses:

Mortality was corrected according to Schneider-Orelli's formula (Püntener, 1981).

\section{Biochemical Changes of Some Haemolymph Enzymes:}

\section{1- Sample Collection:}

Samples of the haemolymph from the previous treatments and control were taken at 2,4 , and 6 days after treatment. The haemolymph was collected through a fine puncture in the hind leg and from beneath the dorsal pronotal shield membrane and transferred into dry centrifuge tubes (Metaweh et al., 2001).

\section{2- Determination of Lactate Dehydrogenase Enzyme:}

The method described here is derived from the method recommended by the German Society for clinical chemistry (DGCK, 1972).

\section{3- Determination of Trehalase Enzyme:}

Trehalase was determined according to the method described by (Ishaaya and Swirski 1976) using trehalose as a substrate for trehalase.

\section{RESULTS AND DISCUSSION}

Figure (1) Show the accumulative mortality caused by $M$. acridum and Neem mixture of them against immature adult $S$. gregaria. $M$. acridum treatment affected mortality after 4 days from inoculation and the mortality reaches $76.6 \%$ after 14 days, while total mortality in case of neem is 26.6 in the same period and the mortality started after 3 days only from treatment, total mortality increased in case of $M$. acridum and Neem mixture to reaches $96.6 \%$ after 14 days. 
Mortality after $M$. acridum treatment is due to toxins release which causes destruction of locust tissues or reduces nutrition, this results in parallel to (Lednev et al., 2008) who found that the mortality started after four days after treatment of Locusta migratoria with $M$. anisopliae. In case of neem the percentage of mortality was lower than M. acridum maybe because neems act as antifeedant which affects the amount of food. While mortality in $M$. acridum and Neem mixture may be accelerated due to stimulation of Neem to the ferocity of $M$. anisopliae this result compatible with (El-Dydamone., 2016) who found the mixture from M. anisopliae and neem makes the acceleration of mortality if compared with them alone, or maybe due to effect of Neem on the immune response of desert locust.

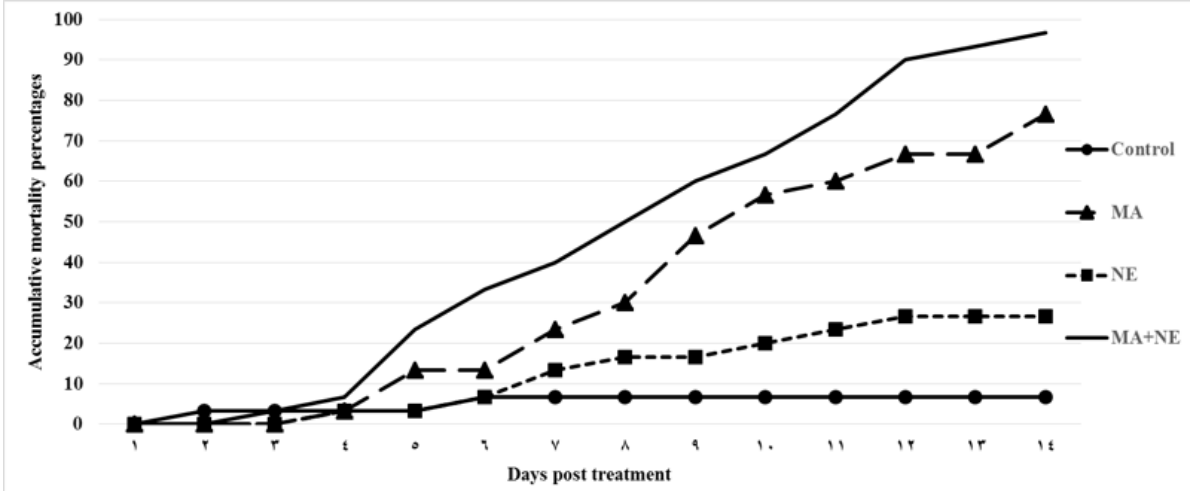

Fig 1: Accumulative mortality due to $M$. acridum, Neem and their mixture against immature adult $S$.gregaria, $\mathrm{MA}=M$. acridum, $\mathrm{NE}=\mathrm{Neem}$.

\section{The Activity of Lactate Dehydrogenase Enzyme (LDH):}

The activity of LDH is decreased than control after 2,4 and 6 days when insect treated with $M$. acridum and neem this result is in parallel to (Soltan, 2009) which found a decrease in the activity of LDH rather than control after1,2 and 3 days when treated $S$. gregaria with $M$. acridum. Such a decrease in LDH activity may be due to the increase in oxygen uptake. While in case of $M$. acridum and Neem mixture the level of LDH enzyme increase than control after 2 days may be due to the Neem increase efficacy of $M$. acridum, in which the insect wants to keep the cell living in important tissue by active energy metabolism, then the level of enzyme decreases than control after 4 and 6 days due to the fungus distribution in all cells (Fig. 2).

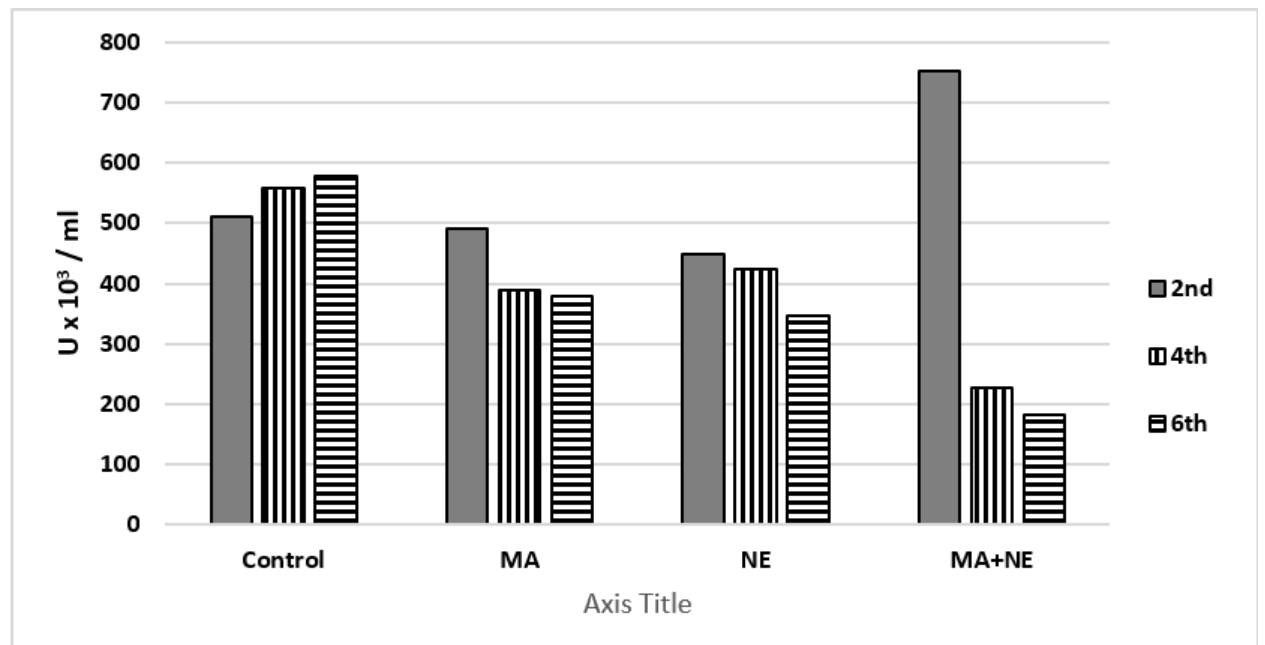

Fig. 2: Effect of M. acridum, Neem and their mixture on lactate dehydrogenase enzyme activity in haemolymph of $S$. gregaria. 


\section{The Activity of Trehalase Enzyme:}

The Activity of trhalase enzyme in $M$. acridum and neem and their mixture on all days of the experiment are lower than control, this decrease due to the toxicity stress of the treatments, (Ishaaya and Swirkski, 1976) reported that trehalse could be used as a parameter for assessing the availability of nutrients. The level in the mixture is lower than M. acridum and Neem alone, due to the Neem increase the severity of $M$. acridum which effect on the activity of insect to degrade trehalose as foul for all biological activity (Fig.3).

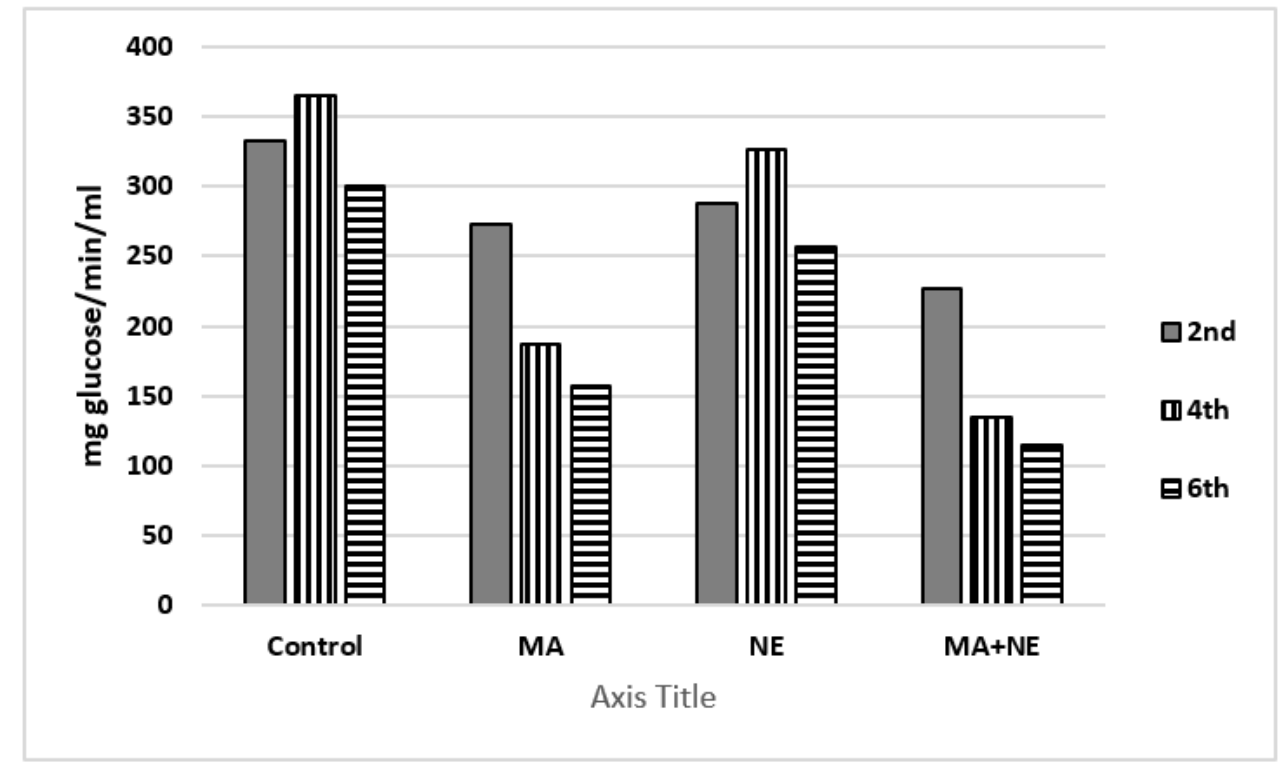

Fig.3: Effect of $M$. acridum, Neem and their mixture on trehalase enzyme activity in haemolymph of Schistocerca gregaria.

\section{REFERENCES}

Abdulhadi Muhammad and Kashere, M. A (2020). Neem, Azadirachta indica L. (A. Juss): an eco-friendly botanical insecticide for managing farmers' insects pest problems- a review. FUDMA Journal of Sciences, Vol 4, No. (4) 484-491.

Becker, A., P. Schlöder, J. E. Steele and G. Wegener (1996). The regulation of trehalose metabolism in insects. Experientia, 52: 433-439.

DGCK, (1972). Deutsche Gesellschaft für Klinische Chemie. Empfehlungen der deutschen Gesellschaft für Klinische Chemie. Standardisierung von Methoden zur Bestimmung von Enzymaktivituten in biologischen Flüssigkeiten. (Recommendation of the German Society of Clinical Chemistry. Standardization of methods for measurement of enzymatic activities in biological fluids.). Z. Klin. Chem. Klin. Biochem., 10:182192.

Diamantino, T. C., E. Amadeu, M. V. M. Soaresa and L. Guilherminoc (2001). Lactate dehydrogenase activity as an effect criterion in toxicity tests with Daphnia magna Straus. Chemosphere, 45: 553-560.

El-Dydamony, M. Kh. (2011). Studies on the impact combind role of growth inhibitor and fungi on the desert locust. M.Sc. Thesis faculty of science (boys) Al-azhar University.

El-Dydamony, M. Kh. (2016). Safe strategy for controlling desert locust Ph.D. Thesis faculty of science (boys) Al-azhar University.

El-Maghraby, M. M. A, E. A. Gomaa, H. H. Metaweh, and G. M. Abdelatef., 2009. Susceptibility of Schistocerca gregaria (Forskal) and Euprepocnemis plorans 
(Charpentier). to Metarhizium anisopliae var. acridum (Metchnikoff) Soroken, Beauveria bassiana (Bals.) Vuill. and Nosema locustae Canning. Egyptian Journal of Biological Pest Control, 19 (1): 55-61.

Hamadah, Kh. Sh., A. L. Basiouny and K. S. Ghoneim (2010). Alterations in the lactate dehydrogenase activity of the desert locust Schistocerca gregaria by the wild plant Fagonia bruguieri (Zygophyllaceae). Egyptian Academic Journal of biological Sciences, (A.Entomology), 3 (2): 1-9.

Hunter-Jones, P. (1961): Rearing and breeding locust in the laboratory. Bulletin Antilocusts Research Center. London. 12.

Ishaaya, I. and E. Swriski (1976) Trehalase, invertase and amylase activities in the black scale, Saissetia oleae, and their relation to host adaptability. Journal of Insect Physiology, 22: 1025-1029.

Jacobson, M. (1989). Botanical pesticides, past, present and future. In: "Insecticides of plant origin". (Arnason, J.T., ed.). Proc. Amr. Chemical Soc. Washington, D. C. 1-10.

Kaplan, L. A. and A. J. Pesce (1996). Clinical Chemistry-theory Analysis and Correlation. Mosby-Year Book, MO, pp. 609-610.

Lednev G. R., Kryukov V. Yu., Khodyrev V. P., Levchenko M. A., Duisembekov B. A., Sagitov A. O. and Glupov V. V. (2008). Dynamics of mortality of the migratory locust under synchronous infection with entomopathogenic fungi (Beauveria bassiana, Metarhizium anisopliae) and bacteria Pseudomonas sp. Contemporary Problems of Ecology volume 1, pages210-213

Lomer, C. J., R. P. Bateman, D. L. Johnson, J. Langewald, and M. Thomas. (2000): Biological control of locusts and grasshoppers. Annual Review of Entomology, 46:667-702.

Metaweh, H. H., E. A. A. Gomaa, R. M. Sherif and T. A. Abdelfattah (2001). Bio chemical changes of the haemolymph of the fifth nymphal instar of the grasshopper, Euprepocnemis plorans plorans after infection with three entomopathogenic fungi. Egyptian Journal of Biological Pest Control, 11(2): 177-182.

Püntener W., 1981 Manual for field trials in plant protection second edition. Agricultural Division, Ciba-Geigy Limited.

Soltan, E. (2009). The effect of entemopathogenic fungus Metarhizium anisopliae var. acridum on flight muscle in the desert locust Schistocerca gregaria (Forskal): Master Thesis, Faculty of Agriculture, Cairo University.

Subrahmanyam, B. and H. Rembold (1989). Effects of azadirachtin A on neuroendocrine activity in Locusta migratoria. Cell Tissue Research, 256: 513-517.

Sumit Moharana, Pallavi Khuntia, Sarthak Suvojit Das, Rituparna Das, Sanjita Panigrahi (2020). A Systematic Review of Behavioral Aspects \& Management Techniques to Control Locusts. International Journal for Science and Advance Research in Technology (IJSART), Volume 6 Issue 7 -361-369.

Wanxi Peng, Nyuk Ling Ma, Dangquan Zhang, Quan Zhoua, Xiaochen Yuea, Shing Ching Khoo, Han Yang, Ruirui Guan ,Huiling Chen, Xiaofan Zhang, Yacheng Wang, Zihan Wei, Chaofan Suo, Yuhao Peng, Yafeng Yang, Su Shiung Lam , Christian Sonne.(2020). A review of historical and recent locust outbreaks: Links to global warming, food security and mitigation strategies. Environmental Research, Volume 191, 110046.

Wegener, G. (1996). Flying insects: model systems in exercise physiology. Experientia, 52; 404-412. 


\section{ARABIC SUMMARY}

الفعل المشترك للنييم و فطر Metarhizium acridum على الحشرات الكامله غير الناضجة جنسيا للجراد

\section{الصحراوى Schistocerca gregaria}

$$
\begin{aligned}
& \text { جمال محمد محمود عبداللطيف و محمد خيرى الايدامونى النى }
\end{aligned}
$$

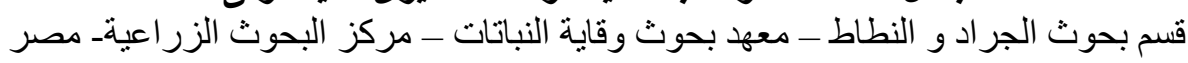

تم اختبار فاعلية النيم و فطر M. acridum وكذلك مخلوطهم على الحشرات الكاملة الغير ناضجة جنسيا.

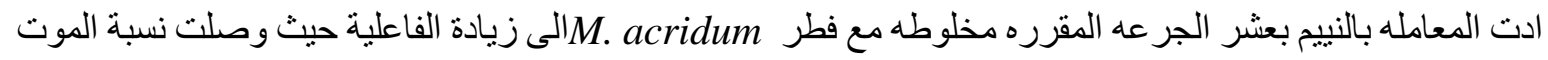

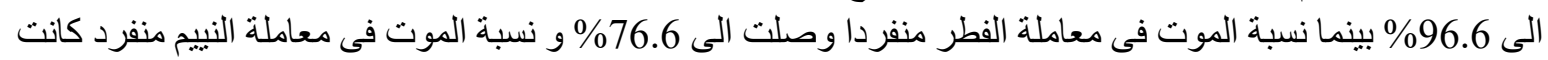

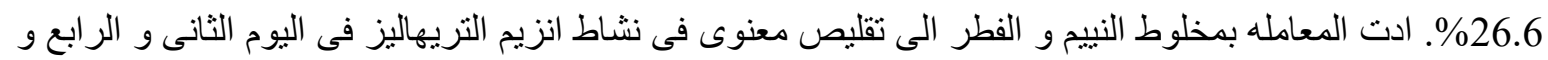

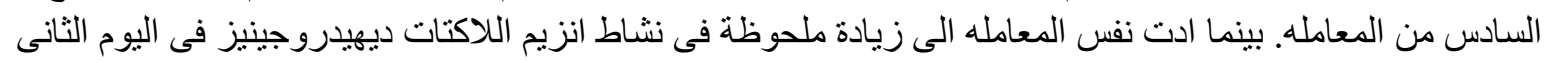
من المعامله بينما انخفض نشاط نفس الأنزيم معنويا بعد ذلك في الأيام الكيام الر ابع و السادس من المعاملة. 